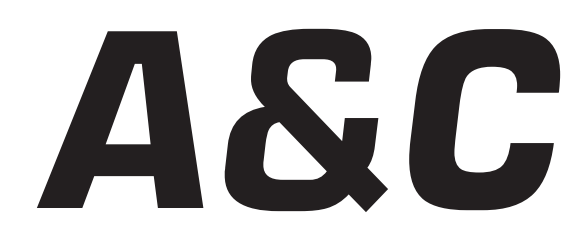

Revista de Direito Administrativo \& Constitucional

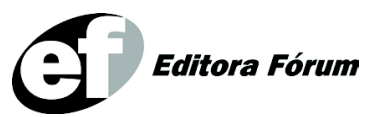

ISSN 1516-3210 


\section{A\&C REVISTA DE DIREITO ADMINISTRATIVO E CONSTITUCIONAL}

IPDA

Instituto Paranaense

de Direito Administrativo

Direção Geral

Romeu Felipe Bacellar Filho

Direção Editorial

Paulo Roberto Ferreira Motta

Direção Executiva

Emerson Gabardo

Conselho de Redação

Edgar Chiuratto Guimarães

Adriana da Costa Ricardo Schier

Célio Heitor Guimarães

\section{Conselho Editorial}

Adilson Abreu Dallari

Alice Gonzáles Borges

Carlos Ari Sundfeld

Carlos Ayres Britto

Carlos Delpiazzo

Cármen Lúcia Antunes Rocha

Celso Antônio Bandeira de Mello

Clèmerson Merlin Clève

Clóvis Beznos

Enrique Silva Cimma

Eros Roberto Grau

Fabrício Motta

Guilhermo Andrés Muñoz (in memoriam)

Jaime Rodríguez-Arana Muñoz

Jorge Luís Salomoni

José Carlos Abraão
José Eduardo Martins Cardoso
José Luís Said
José Mario Serrate Paz
Juan Pablo Cajarville Peruffo
Juarez Freitas
Julio Rodolfo Comadira
Luís Enrique Chase Plate
Lúcia Valle Figueiredo
Manoel de Oliveira Franco Sobrinho
(in memoriam)
Marçal Justen Filho
Marcelo Figueiredo
Márcio Cammarosano
Maria Cristina Cesar de Oliveira

Nelson Figueiredo

Odilon Borges Junior

Pascual Caiella

Paulo Eduardo Garrido Modesto

Paulo Henrique Blasi

Paulo Neves de Carvalho (in memoriam)

Paulo Ricardo Schier

Pedro Paulo de Almeida Dutra

Regina Maria Macedo Nery Ferrari

Rogério Gesta Leal

Rolando Pantoja Bauzá

Sérgio Ferraz

Valmir Pontes Filho

Yara Stropa

Weida Zancaner

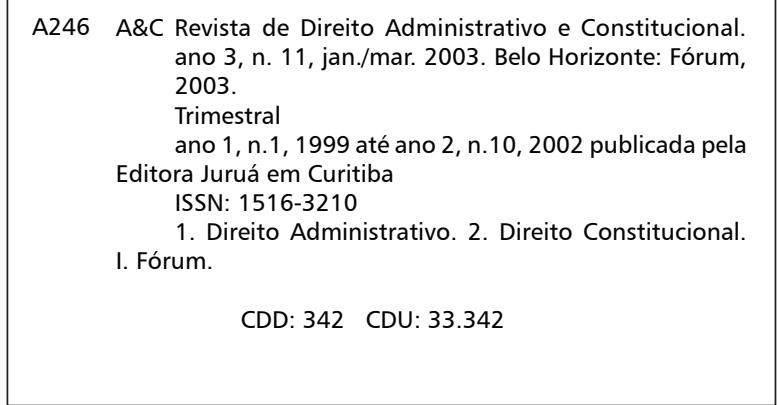

(C) Editora Fórum Ltda. 2007

Todos os direitos reservados. É proibida a reprodução total ou parcial, de qualquer forma ou por qualquer meio eletrônico ou mecânico, inclusive através de processos xerográficos, de fotocópias ou de gravação, sem permissão por escrito do possuidor dos direitos de cópias (Lei nº 9.610, de 19.02.1998).

Editora Fórum Ltda

Av. Afonso Pena, 2770 - 15\%16ª andar - Funcionários

CEP 30130-007 - Belo Horizonte/MG - Brasil

Tel.: 08007043737

Internet: www.editoraforum.com.br

e-mail: editoraforum@editoraforum.com.br
Editor responsável: Luís Cláudio Rodrigues Ferreira Projeto gráfico e diagramação: Luis Alberto Pimenta Revisora: Olga M. A. Sousa

Pesquisa jurídica: Fátima Ribeiro - OAB/MG 74868

Bibliotecária: Alessandra Rodrigues da Silva CRB 2778/MG 6 ${ }^{\text {a Região }}$

Os conceitos e opiniões expressas nos trabalhos assinados são de responsabilidade exclusiva de seus autores.

Impressa no Brasil / Printed in Brazil

Distribuída em todo Território Nacional 


\title{
Superação das antinomias entre a legislação e a Constituição no exercício da advocacia pública*
}

\author{
Cláudio Grande Júnior \\ Procurador do Estado de Goiás. Professor Substituto da Universidade Federal de Goiás. Especialista \\ em Direito Administrativo Contemporâneo pelo Instituto de Direito Administrativo de Goiás - IDAG. \\ Especializando em Direito Constitucional na Universidade Federal de Goiás.
}

Palavras-chave: Antinomias normativas. Controle de constitucionalidade. Controle interno. Interpretação constitucional. Advocacia pública.

Sumário: Introdução - 1 Hodierna advocacia pública - 1.1 Tratamento constitucional - 1.2 Importância para o Estado Democrático e Social de Direito - 2 Controle interno de constitucionalidade e antinomias normativas - 2.1 Parâmetros e objeto do controle interno de constitucionalidade 2.2 Inexecução de leis inconstitucionais pelos chefes de poderes e de órgãos independentes - 2.3 Antinomias normativas e sua superação pela Administração Pública - Conclusões - Referências

\section{Introdução}

O Estado Democrático e Social de Direito prima pela supremacia da Constituição e tem como pedras de toque os princípios da presunção de constitucionalidade dos atos normativos estatais e o da superioridade da lei em relação aos atos administrativos. Por conseqüência, a atual sistemática de controle interno da Administração Pública não é apenas de legalidade, mas de legitimidade, cujos parâmetros de aferição são as normas constitucionais. É perturbador, portanto, o problema da inexecução administrativa das normas legais flagrantemente inconstitucionais, pois, seja seguindo os que a admitem, seja filiando-se à corrente contrária, remanesce sempre um odor de descumprimento da Constituição.

Nessa conjuntura, são salutares os esforços interpretativos voltados à prevenção de antinomias entre normas legais e constitucionais. Com métodos adequados de interpretação é possível reduzir o número de casos em que os Administradores Públicos se vêem obrigados a descumprir leis por entendê-las inconstitucionais. A advocacia pública ganha relevo nesse cenário de controle jurídico de constitucionalidade dos atos administrativos, por trabalhar com parâmetros jurídicos racionais para a

\footnotetext{
* Texto revisto da tese aprovada à unanimidade no XXXII Congresso Nacional de Procuradores de Estado, realizado de 3 a 7 de setembro de 2006, em Natal-RN.
} 
interpretação das normas e o controle dos atos administrativos.

\section{Hodierna advocacia pública}

\subsection{Tratamento constitucional}

Com a consolidação dos direitos e garantias fundamentais, o Estado não pôde mais submeter irresponsavelmente os indivíduos à sua vontade. Para aplicar sanções penais, passou a se sujeitar a um processo penal no qual há separação entre as funções de acusar e julgar, além de o princípio da paridade de armas ter imposto ao Poder Público a obrigação de munir os acusados com a defesa técnica de um advogado. De um modo geral, o Estado não pôde mais satisfazer suas pretensões civis, e mesmo as tributárias, sem observância do devido processo legal. Por outro lado, admitida a possibilidade de responsabilização estatal por danos causados a terceiros, o Estado precisou contar com advogados para se defender em juízo.

Por isso, tradicionalmente, se diz que a advocacia pública engloba as funções de acusação penal pública, fiscalização dos interesses indisponíveis, assistência judiciária aos necessitados e representação judicial e consultoria jurídica às entidades estatais. Em linhas gerais, compreende as atribuições do Ministério Público (advocacia da sociedade), da Defensoria Pública (advocacia dos necessitados) e da Advocacia Estatal. É o que hoje se pode chamar de advocacia pública latu sensu. Esse sentido foi o originalmente empregado pelo constituinte, ao assentar as Funções Essenciais à Justiça, em 1988. Lembra Diogo de Figueiredo Moreira Neto que, a partir da distinção entre advocacia privada e pública, institui-se a subdivisão desta, tomada no seu sentido lato, em três ramos: o Ministério Público, a Advocacia de Estado e a Defensoria Pública, postando-as como Procuraturas Constitucionais. ${ }^{1}$

Atualmente, contudo, pode-se falar na advocacia pública strictu sensu, entendida apenas como Advocacia de Estado, em razão de a Emenda Constitucional no 19/98 ter renomeado, como "Da Advocacia Pública", a Seção II do Capítulo IV do Título IV da Constituição da República. A dita seção trata da Advocacia-Geral da União, da Procuradoria-Geral da Fazenda Nacional e dos Procuradores dos Estados e do Distrito Federal. Assim, em que pese as críticas, ${ }^{2}$ emprega-se, no presente trabalho, a noção de Advocacia Pública em sentido estrito, entendida como a função per-

${ }^{1}$ MOREIRA NETO. Advocacia pública e o princípio da eficiência. Interesse Público.

A \& C R. de Dir. Administrativo e Constitucional, Belo Horizonte, ano 7, n. 28, p. 45-75, abr./jun. 2007 
manente, constitucionalmente essencial à Justiça e ao Estado Democrático de Direito, que compreende o conjunto de atividades atinentes à representação judicial e extrajudicial das pessoas jurídicas de direito público e judicial dos órgãos, conselhos e fundos administrativos excepcionalmente dotados de personalidade judiciária, bem como à prestação de consultoria, assessoramento e controle jurídico interno a todas as desconcentrações e descentralizações verificáveis nos diferentes Poderes que juntos constituem a entidade federada. ${ }^{3}$

Os advogados públicos são organizados em carreiras, de acordo com a esfera federativa a que estão vinculados. Desse modo, temos a Advocacia-Geral da União, as Procuradorias-Gerais dos Estados e do Distrito Federal e as Procuradorias-Gerais dos Municípios, todas integradas por advogados públicos. Daí se conclui que advogado público é gênero, do qual, entre nós, são espécies o Advogado da União, o Procurador da Fazenda Nacional, o Procurador Federal, o Procurador do Banco Central, o Procurador do Estado, o Procurador do Distrito Federal e o Procurador do Município, bem como os Assessores, Consultores e Técnicos Jurídicos abrigados pela regra de transição do art. 69 do ADCT. Por seu turno, o art. $9^{\circ}$ do Regulamento Geral do Estatuto da Advocacia e da $\mathrm{OAB}$ apresenta um rol exemplificativo de advogados públicos. ${ }^{4}$

Chama a atenção o tratamento assimétrico dispensado pela Constituição à advocacia pública. Para a União (art. 131) foram previstas a Advocacia-Geral da União (AGU) e a Procuradoria-Geral da Fazenda Nacional (PGFN). A primeira representa judicial e extrajudicialmente a União. Não é apenas a representação do Poder Executivo, mais do que isso é a da União como um todo, compreendendo seus três Poderes, Executivo, Legislativo e Judiciário, e o Ministério Público. Estranhamente, as funções de consultoria e assessoramento jurídico estão restritas ao Poder Executivo, dando a entender que os demais Poderes e o Ministério Público podem ter suas próprias assessorias jurídicas. O equívoco resulta

\footnotetext{
MOREIRA NETO. Advocacia pública e o princípio da eficiência. Interesse Público.

GRANDE JÚNIOR. A advocacia pública no Estado democrático de direito. Boletim Doutrina ADCOAS, p. 450-451.GRANDE JÚNIOR. O Estado do Paraná.

${ }^{4}$ GRANDE JÚNIOR. O controle interno de constitucionalidade exercido pelas procuradorias-gerais dos Estados e do Distrito Federal. In: CONGRESSO NACIONAL DE PROCURADORES DE ESTADO, 31, 2005, Florianópolis. As perspectivas da advocacia pública e a nova ordem econômica, p. 258

GRANDE JÚNIOR. O controle interno de constitucionalidade exercido pelas Procuradorias-Gerais dos Estados e do Distrito Federal. Fórum Administrativo - Direito Público - FA, Belo Horizonte, p. 6387. GRANDE JÚNIOR. Revista de Doutrina da $4^{a}$ Região, mar. 2006.
} 
do fato do Poder Executivo capturar a maior parte da atividade administrativa e, pois, dirigir o conjunto de órgãos e entidades componentes da Administração Pública. Conseqüentemente, as atividades de assessoramento e consultoria estarão voltadas predominantemente para esse Poder. ${ }^{5}$ A Procuradoria-Geral da Fazenda Nacional, por sua vez, existe especificamente para representar a União na cobrança da dívida ativa de natureza tributária. Indiretamente escorada no art. 131, que prevê a representação da União diretamente pela AGU, ou órgão a esta vinculado, a Lei n ${ }^{\circ}$ 10.480/02 criou a Procuradoria-Geral Federal, vinculada à AGU e encarregada da representação judicial e extrajudicial das autarquias e fundações públicas federais e das respectivas atividades de consultoria e assessoramento jurídicos, bem como da apuração da liquidez e certeza dos créditos dessas entidades.

A representação judicial e a consultoria jurídica dos Estados e Distrito Federal foram incumbidas aos Procuradores de Estado e do Distrito Federal (art. 132). O constituinte foi mais coerente ao não restringir a consultoria apenas ao Poder Executivo, porém silenciou acerca do assessoramento jurídico. O art. 132 determina, outrossim, que os Procuradores sejam organizados em carreira. Esta se materializa na instituição chamada de Procuradoria-Geral do Estado ou do Distrito Federal, sem olvidar que algumas Constituições Estaduais preferiram outras denominações, como a Advocacia-Geral do Estado.

Por fim, a Constituição de 1988 nada dispõe especificamente sobre a advocacia pública no âmbito municipal. Talvez um lapso decorrente da então recente inclusão dos Municípios no pacto federativo. Em parte verdade, pois Cesar Antonio Alves Cordaro esclarece que a quantidade de Municípios e a diversidade de situações engessariam essas unidades estatais se tratadas todas igualmente, impondo um encargo excessivo a pequenas localidades, "jejunas de recursos e, muitas vezes, sem a real necessidade de serviço jurídico estruturado nas proporções de uma Procuradoria Geral". ${ }^{6}$

Mas é fato incontroverso que os Municípios, como entidades estatais, estão investidos de autonomia político-administrativa e, conseqüentemente, possuem personalidade jurídica de direito público interno.

\footnotetext{
5 OMMATI, Fides Angélica. Advocacia pública - algumas reflexões. Jus Navigandi.

6 CORDARO, Cesar Antonio Alves. A Advocacia Pública e os Municípios. Revista Trimestral de Advocacia Pública, p. 12-13.
}

A \& C R. de Dir. Administrativo e Constitucional, Belo Horizonte, ano 7, n. 28, p. 45-75, abr./jun. 2007 
Destarte, necessitam de representação judicial e extrajudicial. E, como seus agentes políticos devem rigorosa observância à Constituição e aos princípios da administração pública, torna-se imperioso reconhecer o "necessário assessoramento técnico, através de um órgão especializado, estruturado através de cargos acessíveis mediante concurso de provas e títulos, cujos ocupantes tenham a garantia da estabilidade". ${ }^{7}$ Por outro lado, é inegável a existência de Municípios sem condições de instituírem e estruturarem autênticas Procuradorias. Logo, inteligente é a solução de Emenda Constitucional, estabelecendo critério de obrigatoriedade vinculado ao número de habitantes. ${ }^{8}$ Ainda assim, todas as municipalidades precisam, ao menos, criarem cargos de provimento efetivo de advogados públicos.

\subsection{Importância para o Estado Democrático e Social de Direito}

Os interesses patrocinados pelos advogados públicos não são nem os do governo nem os dos governantes. As conveniências destes são patrocinadas por advogados particulares, ao passo que aquele significa somente a condução política das atividades estatais e sequer tem personalidade jurídica. Os interesses patrocinados são os do Estado, entendido como a entidade estatal e as pessoas jurídicas que integram sua administração indireta. Não se pode confundir a defesa do Estado com defesa do governo, se bem que, por vezes, possa isso ocorrer, eis que este dá tônica à atuação estatal. Em suma, deve-se ter sempre em vista que o patrocínio do Estado consiste exatamente na defesa dos interesses que a pessoa pública encarna e é vocacionada a realizar. ${ }^{9}$

Tais vocações estatais evoluíram e se transformaram ao longo da história. O Estado de direito passou por duas fases, a liberal e a social, antes de alcançar o atual estágio democrático. Do mesmo modo, a advocacia pública acompanhou essas feições.

Originalmente, a postura do Estado de Direito era abstencionista, coadunando-se com os princípios liberais então vigentes. Carlos Ari Sundfeld assinala as pedras de toque do Estado Liberal de Direito: (i) supremacia da Constituição; (ii) separação dos Poderes; (iii) superioridade da lei; e (iv) garantia dos direitos individuais. ${ }^{10}$ A preocupação era apenas de

CORDARO, Cesar Antonio Alves. A Advocacia Pública e os Municípios. Revista Trimestral de Advocacia Pública.

8 CORDARO, Cesar Antonio Alves. A Advocacia Pública e os Municípios. Revista Trimestral de Advocacia Pública.

9 OMMATI, Fides Angélica. Advocacia pública - algumas reflexões. Jus Navigandi. 
impor limites à Administração Pública. Por outro lado, curiosamente, ela tinha ampla liberdade para fazer o que bem entendesse, sem preocupações formais e procedimentais, desde que respeitasse aqueles limites e não causasse prejuízos a terceiros. Posteriormente, adveio o anteparo legal contra o patrimonialismo, o clientelismo e o nepotismo, ${ }^{11}$ contudo o sentido da legalidade ainda era restrito à simples vinculação negativa expedida pelo Poder Legislativo. Respeitada essa baliza, a Administração Pública tinha amplo poder discricionário de atuação. Como o Estado pouco agia e quando o fazia tinha amplo espaço de manobra, era praticamente dispensável a advocacia preventiva de assessoramento e consultoria jurídica. Mas, à medida que se desenvolviam as teorias objetivas de responsabilização estatal, surgia nas nações ocidentais a advocacia estritamente pública, voltada para o patrocínio dos interesses próprios da pessoa jurídica de direito público, que nem sempre se confundem com os dos agentes públicos. Até então, a responsabilidade do Estado se confundia com a do agente, de modo que a defesa de um implicava sempre na do outro. ${ }^{12}$

As intempéries econômicas e seus conseqüentes enxurros sociais exigiram do Estado um papel ativo. "O Estado deixa seu papel não intervencionista para assumir nova postura: a de agente do desenvolvimento e da justiça social", por meio de prestações estatais positivas, passíveis, inclusive, de serem exigidas pelos indivíduos. Surge o Estado Social de Direito, agregando-se aos fundamentos já vistos do Estado de Direito um novo baldrame: (v) direitos sociais correspondentes ao dever de atuação positiva do Estado na geração de desenvolvimento e justiça social. ${ }^{13}$ Daí resultou a crescente intervenção social e econômica do Estado, propulsionando a evolução rumo à advocacia pública social. Cresceu, por um lado, a possibilidade de danos a terceiros e, de outro, as hipóteses de favoritismos e perseguições. Em reação, desenvolveram-se melhor os princípios da impessoalidade, da moralidade e da publicidade. Mas o núcleo do sistema continuava a ser o princípio da legalidade, cuja acepção foi alargada com a vinculação positiva do administrador público, surgindo a difundida idéia de que a Administração só pode fazer o que a lei permite. Além disso, a idéia de legalidade se ampliou, para alcançar outros atos normativos, além

\footnotetext{
10 SUNDFELD. Fundamentos de direito público, p. 39, 40.

${ }^{11}$ MOREIRA. Direito administrativo: da rigidez autoritária à flexibilidade democrática, p. 403

12 GRANDE JÚNIOR. O controle interno de constitucionalidade exercido pelas procuradorias-gerais dos Estados e do Distrito Federal. In: CONGRESSO NACIONAL DE PROCURADORES DE ESTADO, 31, 2005, Florianópolis. As perspectivas da advocacia pública e a nova ordem econômica, p. 255

13 SUNDFELD. Fundamentos de direito público, p. 55.
} 
da lei em sentido estrito. Teceu-se o fio condutor da publicação de uma enormidade de leis e atos normativos administrativos, complicadora da atuação legal dos gestores públicos, que, antes da prática de atos administrativos, se vêem obrigados a seguirem um procedimento de consulta aos advogados públicos. ${ }^{14}$

Inicialmente, as preocupações de consultoria, assessoramento jurídico e controle interno se voltavam apenas para a legalidade do ato e às formalidades exigidas para sua prática, sem questionamentos outros sobre a finalidade pública, publicidade, moralidade, razoabilidade, proporcionalidade ou eficiência. Acreditava-se cegamente na dogmática jurídica positivista de que a lei poderia regular direta ou indiretamente todas as variáveis fáticas, o que repropulsionava ainda mais a produção normativa. Porém, longe de conter a atuação desmerecida de administradores e funcionários públicos, a excessiva produção legislativa acarrancou o funcionamento da máquina estatal. Uma infinidade de normas deve ser obedecida para a concretização de atos administrativos simplórios. Restringindo-se à análise formal dos atos, apontando o iter legal a ser obedecido e toda sorte de restrições legais, os advogados públicos são mal vistos, como os legalistas claudicantes da Administração Pública. ${ }^{15}$

Tal concepção de Estado também se mostrou insuficiente em face das atrocidades do nazismo, do fascismo e dos diversos regimes, tanto de direita como de esquerda, que floresceram e murcharam, maculando o arcabouço teórico do Estado Social de Direito. "A idéia de um ordenamento jurídico indiferente a valores éticos e da lei como uma estrutura meramente formal, uma embalagem para qualquer produto, já não tinha mais aceitação no pensamento esclarecido." 16

A superação do estigma reside no reconhecimento de direitos humanos universais, independentes da nacionalidade, na aceitação da democracia e na limitação de seu exercício à supremacia do sistema constitucional promulgado. O poder democrático tem ampla liberdade, desde que se coadune com a ordem constitucional pluralista de uma sociedade aberta, que respeita os direitos fundamentais de todos, inclusive

\footnotetext{
${ }^{14}$ GRANDE JÚNIOR. O controle interno de constitucionalidade exercido pelas procuradorias-gerais dos Estados e do Distrito Federal. In: CONGRESSO NACIONAL DE PROCURADORES DE ESTADO, 31, 2005 Florianópolis. As perspectivas da advocacia pública e a nova ordem econômica, p. 256.

${ }^{15}$ GRANDE JÚNIOR. O controle interno de constitucionalidade exercido pelas procuradorias-gerais dos Estados e do Distrito Federal. In: CONGRESSO NACIONAL DE PROCURADORES DE ESTADO, 31, 2005, Florianópolis. As perspectivas da advocacia pública e a nova ordem econômica, p. 256

${ }^{16}$ BARROSO, Luís Roberto. Fundamentos teóricos e filosóficos do novo direito constitucional brasileiro (Pósmodernidade, teoria crítica e pós-positivismo). Revista Diálogo Jurídico.
} 
das minorias, e o meio ambiente. Desse raciocínio emerge o ideal do Estado Democrático de Direito, cujos alicerces são: (i) supremacia da Constituição; (ii) separação dos Poderes; (iii) superioridade da lei; (iv) garantia dos direitos individuais; e (v) garantia dos direitos políticos e de participação, respeitando-se o pluralismo, as diferenças e o meio ambiente. Assim, a supremacia constitucional ganha uma conotação mais forte porque mesmo a democracia deve a ela se sujeitar, em garantia aos direitos de participação e de diferença das minorias, que não podem ser exterminados pelas maiorias momentâneas ou mesmo perenes. Evita-se, assim, que o Estado Democrático seja destruído por sua própria força criadora: a das massas. Assevera Paulo Bonavides:

As massas, no Estado jurídico, já têm o poder de intervir na formação da vontade estatal. Cumpre evitar apenas que esse poder se demude em poder de destruir o Estado social da democracia, porque, se assim fora, estariam atraiçoadas não as instituições democráticas, senão as mesmas massas, que haveriam solapado inconscientemente os seus mais caros interesses, vendo cair das mãos o poder do voto, ou seja, a maior arma de libertação política e social que o Homem moderno já conheceu. ${ }^{17}$

Segundo Konrad Hesse, a Constituição democrática deixa conscientemente abertas as mais variadas questões. Mas, como ordem jurídica fundamental, não pode deixar em aberto as bases da ordem da coletividade, aquilo que já foi decidido e não mais pode ser posto em dúvida, ${ }^{18}$ a saber, os direitos fundamentais, a democracia, a organização básica dos Poderes e os principais procedimentos.

Avançando para um Estado de direito tanto social como democrático, suas pedras angulares correspondem à soma dos elementos acima vistos: (i) supremacia da Constituição; (ii) separação dos Poderes; (iii) superioridade da lei; (iv) garantia dos direitos individuais; (v) garantia dos direitos políticos e de participação, respeitando-se o pluralismo, as diferenças e o meio ambiente; e (vi) direitos sociais correspondentes ao dever de atuação positiva do Estado na geração de desenvolvimento e justiça social.

Respeitando e partindo desses sólidos alicerces fundamentais, a democracia está em contínua construção. Não é um projeto acabado, dotado de estrutura inequívoca e imutável, cristalizada num modelo pronto. É um processo de construção diário e, por isso, inacabado. ${ }^{19} \mathrm{Com}$

17 BONAVIDES. Do Estado liberal ao Estado social, p. 200.

${ }^{18}$ HESSE. Elementos de direito constitucional da República Federal da Alemanha, p. 37-43.

A \& C R. de Dir. Administrativo e Constitucional, Belo Horizonte, ano 7, n. 28, p. 45-75, abr./jun. 2007 
efeito, o funcionamento desse sistema foi aprimorado, escapando-se da limitada capacidade normativa das regras, que outrora se confundiam com as disposições legais escritas. Sabe-se, agora, que o dispositivo legal ou constitucional é apenas a fonte de onde se extrai a norma, que resulta sempre de um trabalho interpretativo. Mais do que isso, reconheceu-se a normatividade dos princípios, que, ao lado das regras, constituem espécie do gênero norma.

Hodiernamente, todos os ramos do direito, e com mais razão o direito administrativo, devem ser aplicados a partir dessa ótica constitucional. Por um lado, a constitucionalização se deu com a expressa inserção da Administração Pública e de seus princípios no texto da Constituição. Tal fato é importante porque, como não existe hierarquia entre as normas constitucionais, todos os princípios essenciais enumerados no art. 37 estão em pé de igualdade. Na eventual hipótese de colisão, a preponderância de algum deles deve ser analisada no caso concreto. Todavia, a constitucionalização não pára aí, vai muito mais longe, porquanto todas as normas constitucionais direcionam a construção, seja legislativa ou interpretativa, do direito administrativo. Este não pode, em momento algum, contrariar o sistema constitucional, principalmente seu núcleo: a dignidade da pessoa humana, que por conseqüência lógica passa a ser também o do direito administrativo. Assim, o papel da advocacia pública no controle interno do Estado Democrático e Social de Direito não pode se restringir à mera legalidade em sentido estrito. Enquadra-se na preleção de João Batista Gomes Moreira:

Nesta nova postura, a vinculação da Administração é à lei e ao Direito, como, aliás, está na Lei brasileira de processo administrativo (Lei n. ${ }^{\circ}$ 9.784/99). O Estado de Direito, na sua concepção teórica mais perfeita — diz Jhering —, é uma espécie de tear executando com precisão os movimentos prescritos pela lei, mas a esse modelo faltaria vitalidade. (...) O excesso de zelo é tão pernicioso quanto a impunidade.

No Estado social, ao princípio da legalidade da Administração Pública acrescentam-se, tomando como referência a Constituição brasileira, os princípios da moralidade, impessoalidade, publicidade e eficiência, de forma entrelaçada e reciprocamente instrumentalizada. (...) A subordinação àqueles outros princípios colocados expressamente na Constituição, principalmente ao princípio da eficiência, é indicação segura de que os trilhos da Administração não mais se limitam à lei strictu sensu (...).

O princípio da legalidade, mesmo para o administrador, deve ser compreen-

${ }^{19}$ STRECK; MORAIS. Ciência política e teoria geral do estado, p. 115-123.

A \& C R. de Dir. Administrativo e Constitucional, Belo Horizonte, ano 7, n. 28, p. 45-75, abr./jun. 2007 
dido não como um limite intransponível, mas uma das referências na promoção do interesse público primário - que nem sempre coincide com a expressão literal da lei - a partir das normas e princípios constitucionais. Antes não se admitia pudesse a Administração reportar-se autônoma e diretamente à Constituição, todavia, tendo-se nesta inserido um capítulo específico da Administração Pública, parece indiscutível tal abertura ao agente administrativo, dentro de sua esfera de competência, e não apenas ao juiz.

(...)

Inicialmente concebido sob a feição de um puro legalismo, o princípio da legalidade caminhou para a substantivação. Na nova perspectiva, pode-se considerar que os demais princípios são coadjuvantes, senão aspectos, da legalidade (...).

Visto sob todos esses aspectos, o princípio da legalidade vem adquirindo, ao longo do tempo, a versão de princípio da legitimidade (Diogo de Figueiredo Moreira Neto), princípio da juridicidade (Eduardo Soto Kloss e Cármen Lúcia Antunes Rocha) e princípio da constitucionalidade (Juarez Freitas) ou da supremacia constitucional.

(...) O controle de legalidade da Administração quer dizer hoje, ao mesmo tempo, controle de constitucionalidade; significa que também se controla a Administração em relação ao cumprimento do sistema de valores da Constituição. Verifica-se o que se convencionou chamar "ativismo constitucional da Administração Pública", a ponto de afirmar-se que o direito administrativo é (ou deve ser) o direito constitucional concretizado. ${ }^{20}$

Importante no antigo controle interno de legalidade, a advocacia pública é decisiva no atual sistema de controle interno de legitimidade, juridicidade ou constitucionalidade, subsidiando o ativismo constitucional da Administração Pública, que dinamiza o direito administrativo como concretização constitucional.

\section{Controle interno de constitucionalidade e antinomias normativas 2.1 Parâmetros e objeto do controle interno de constitucionalidade}

Juliano Taveira Bernardes explica que o significado do vocábulo controle guarda relação com a questão da existência de limites. Estes devem ser preestabelecidos, para que o controle possa ser racionalmente exercido. No que aqui interessa, os limites estão fixados pelas normas constitucionais, pois gozam de supremacia no ordenamento jurídico.

Conquanto radicado na concepção da constituição como norma fundamental num dado ordenamento jurídico, o controle de constitucionalidade converte-se no veículo pelo qual se tornam efetivas as exigências traçadas pelo constituinte à regularidade dos atos praticados por indivíduos ou entidades que devem

${ }^{20}$ MOREIRA. Direito administrativo: da rigidez autoritária à flexibilidade democrática, p. 404-407. 
obediência às normas constitucionais.

(...)

Neste ponto, já se pode afirmar: controle de constitucionalidade é o conjunto de mecanismos dispostos para garantir a supremacia constitucional por meio da identificação e eventual reparação de condutas incompatíveis a determinadas normas constitucionais. ${ }^{21}$

Foi visto que o controle interno não é mais apenas de legalidade. É de legitimidade, de juridicidade ou, o termo aqui preferido, de constitucionalidade, porque visa confinar a prática dos atos administrativos às possibilidades permitidas pela ordem constitucional vigente, expurgando atos inconstitucionais e impedindo situações afrontosas à Constituição. Resumindo em outras palavras: evitar inconstitucionalidades perpetradas pela Administração.

"Não se perca de vista o vício sobre o qual incide a atenção do controle de constitucionalidade. A inconstitucionalidade é a designação da relação estabelecida entre a constituição e um comportamento que lhe seja incompatível." 22 Por ser uma relação, de um lado existem os parâmetros e de outro os objetos do controle. Os primeiros são as normas constitucionais vigentes. ${ }^{23}$ Estas formam o bloco de constitucionalidade, expressão que realça a idéia de solidez e unidade dos princípios e regras constitucionais. Os objetos de fiscalização são todos os atos que possam agredir a Constituição.

Destarte, não se pode resumir o objeto de controle aos atos normativos, pois tanto a omissão quanto até mesmo atitudes de particulares podem representar inconstitucionalidades. Sem embargo, costumou-se reservar a expressão controle de constitucionalidade, em sentido estrito, para designar somente a verificação da compatibilidade constitucional de atos jurídicos dotados de abstração e generalidades. ${ }^{24}$

No controle interno de constitucionalidade, o objeto de fiscalização se restringe aos atos administrativos, não todos, porém, somente os emanados pelo próprio Poder (Executivo, Legislativo, Judiciário ou Minis-

\footnotetext{
${ }^{21}$ BERNARDES. Controle abstrato de constitucionalidade: elementos materiais e princípios processuais, p. 19.

22 BERNARDES. Controle abstrato de constitucionalidade: elementos materiais e princípios processuais, p. 24.

${ }^{23}$ Vale reforçar: somente as vigentes. Significa o aspecto temporal do parâmetro de controle, pois a preocupação é com a integridade da ordem constitucional vigente (cf. BERNARDES. Controle abstrato de constitucionalidade: elementos materiais e princípios processuais, p. 121).
} 
tério Público) que se autofiscaliza. Mas nem todos os órgãos ou agentes de um Poder são titulares da atribuição de controle interno. Ainda que se admita a existência de controle de constitucionalidade não institucionalizado, exercido pela própria sociedade, os cidadãos, opinião pública, associações e sindicatos que se opõem ao cumprimento de norma inconstitucional (controle social de constitucionalidade) ${ }^{25}$ os controles de constitucionalidade desempenhados pelo Poder Público são necessariamente institucionalizados, obedecendo a uma lógica racional de hierarquia e distribuição de tarefas. ${ }^{26}$ Somente a alguns órgãos pode ser confiada a titularidade do controle interno, do contrário ruiriam a coordenação e subordinação necessárias para a Administração Pública. Difere, pois, do chamado controle orgânico, identificado por Antônio Flávio de Oliveira, que resulta do dever de todos os agentes públicos de reflexamente fiscalizar a Administração quando do desempenho de suas atribuições. ${ }^{27}$ Conforme visto alhures, à advocacia pública tem o ordenamento jurídico, em maior ou menor grau, conferido a atribuição de controle interno.

Os controles de constitucionalidade do tipo institucional estão assentados no reconhecimento de competência para a fiscalização. Citando Manuel Aragón, Juliano Taveira Bernardes memora que os controles institucionalizados podem ser político ou jurídico. A diferença não recai sobre o objeto de controle. "O traço distintivo é que o controle jurídico se encontra atrelado a parâmetro jurídico indisponível (parâmetro de caráter objetivo), enquanto o controle político trabalha com parâmetros subjetivos (não normativos)". Estes são pautados pela livre apreciação do órgão controlador, que tem ampla liberdade de critério, pois seu juízo de valoração repousa em razões políticas (vantagem, conveniência e oportunidade), ao passo que a outra forma de controle opera sob racionalidade jurídica, baseada em regras de interpretação e aplicação das normas. ${ }^{28}$ A diferença não reside no órgão que exerce o controle, embora

\footnotetext{
${ }^{24}$ BERNARDES. Controle abstrato de constitucionalidade: elementos materiais e princípios processuais, p. 24.

${ }^{25}$ ARAGÓN. Constitución, democracia y control.

${ }^{26}$ KELSEN. Teoria pura do direito, p. 300-306.

27 O controle orgânico está disperso pelo ordenamento jurídico, como, por exemplo, nos vários estatutos de servidores públicos, quando impõem o dever de levar ao conhecimento da autoridade superior as irregularidades de que o servidor tiver ciência em razão do cargo, e no crime de condescendência criminosa, tipificado no Código Penal: Art. 320 - Deixar o funcionário, por indulgência, de responsabilizar subordinado que cometeu infração no exercício do cargo ou, quando lhe falte competência, não levar o fato ao conhecimento da autoridade competente: Pena - detenção, de quinze dias a um mês, ou multa (cf. OLIVEIRA. Precatórios: aspectos administrativos, constitucionais, financeiros e processuais).
} 
Aragón admita que as garantias e prerrogativas conferidas ao Poder Judiciário proporcionem condições para se afirmar que o controle jurisdicional seja o controle jurídico por excelência. Daí o autor conclui que os controles administrativos, mesmo que em muitos casos realizados atendendo razões de direito, não podem ser considerados, em sentido estrito, como puros controles jurídicos, dadas as relações de subordinação a que se submetem os órgãos de controle, o que não garante objetividade, imparcialidade e independência para suas decisões. ${ }^{29}$

Sem dúvida, o controle exercido pela advocacia pública é institucionalizado e jurídico. As dificuldades acima vislumbradas para um controle administrativo interno propriamente jurídico são perfeitamente superáveis, admitindo-se: (i) que a advocacia pública é ofício tipicamente estatal, materializado em fidedigna carreira de Estado, cujos cargos não podem ser de provimento comissionado, o que obsta a contratação de advogados ou escritórios de advocacia pelo Poder Público; (ii) a existência de garantias (por exemplo, vitaliciedade e inamovibilidade) e prerrogativas (como as de requisitar informações, documentos e diligências) para o seu perfeito exercício; (iii) a independência funcional dos advogados públicos e a autonomia institucional das Procuradorias-Gerais e Advocacias-Gerais; (iv) a escolha do Procurador-Geral ou Advogado-Geral dentre membros da carreira, conferindo maior seriedade técnica ao controle interno desempenhado; e (v) a não responsabilização da autoridade competente que age amparada em parecer jurídico razoavelmente fundamentado, ainda que eventualmente equivocado.

Nesse ponto, Bernardes destoa de Aragón, salientando que a independência não é prerrogativa exclusiva do Judiciário. "Daí, se o parâmetro e o juízo valorativo forem jurídicos, o modo de controle institucionalizado o será também, uma vez que não são somente os órgãos judiciais que realizam interpretação preocupada com o valor jurídico-normativo (e não somente político) da constituição". ${ }^{30}$

\subsection{Inexecução de leis inconstitucionais pelos chefes de poderes e de órgãos independentes}

Outrora, quando simplesmente de legalidade o controle interno,

\footnotetext{
28 BERNARDES. Controle abstrato de constitucionalidade: elementos materiais e princípios processuais, p. 30.

${ }^{29}$ ARAGÓN. Constitución, democracia y control, p. 137, 138.
} 
seus parâmetros de controle se restringiam às normas infraconstitucionais. Os mais elevados parâmetros se encontravam nas leis complementares e ordinárias, bem como nos decretos-leis, vez que estes se situavam no mesmo patamar hierárquico daquelas. Quanto às normas constitucionais, somente as de eficácia plena e contida serviam de parâmetro, e desde que não existisse norma infraconstitucional em sentido oposto ainda não declarada inconstitucional pelo Poder Judiciário. Do contrário, a Constituição deveria ser afastada e aplicada a norma inferior, mesmo se explicitamente contrária àquela. À guisa de exemplo, a Administração Pública e seu sistema de controle interno não poderiam se reportar ao art. 37, IV, da Constituição Federal, caso existisse uma lei ainda não declarada inconstitucional concedendo aos novos concursados prioridade para a nomeação em cargo público em detrimento dos anteriormente aprovados em concurso público com prazo de validade ainda não vencido. A rígida idéia de superioridade da lei e a inexistência de vinculação direta da Administração à Constituição, abandonavam o agente público impotente diante da visível antinomia entre a norma constitucional e a legal. Se fosse necessário nomear alguém para os cargos, o agente público deveria, sob pena de ser responsabilizado, convocar os aprovados no último concurso, prejudicando quem tinha preferência constitucional.

Felizmente, houve eficaz oposição à tamanha ortodoxia. Gilmar Ferreira Mendes ressalta que, antes da introdução no Brasil do controle abstrato de constitucionalidade pela Emenda Constitucional n ${ }^{\circ} 16 / 65$, era plenamente majoritária a doutrina avalizando a recusa de cumprimento de lei reputada inconstitucional, destacando-se Carlos Maximiliano, no seu lendário Comentários à Constituição de $1891 .{ }^{31}$ Pragmática, a jurisprudência do Supremo Tribunal Federal compartilhava desse entender, na forma dos seguintes julgados paradigmáticos: RMS 4211/PB, Rel. Min. Candido Motta, DJ, 16 ago. 1957; RMS 5860/SP, Rel. Min. Villas Boas, Julgado aos 05 nov. 1958; RE 55718/SP, Rel. Min. Hermes Lima, DJ, 24 mar. 1965; e RMS 14557/SP, Rel. Min. Candido Motta, DJ, 23 jun. $1965 .{ }^{32}$

\footnotetext{
${ }^{30}$ BERNARDES. Controle abstrato de constitucionalidade: elementos materiais e princípios processuais, p. $39,40$.

${ }^{31} \mathrm{O}$ autor cita também Themistocles Brandão Cavalcanti, Caio Mário da Silva Pereira e Miguel Reale. Apontase ainda: Vicente Ráo, José Frederico Marques, Caio Tácito (cf. BINENBOJM. A nova jurisdição constitucional brasileira: legitimidade democrática e instrumentos de realização, p. 233, 234), e Francisco Campos (cf. SUNDFELD. Princípio da impessoalidade e abuso e abuso do poder de legislar. Revista Trimestral de Direito Público, p. 175). Em sentido oposto, destacava-se na corrente minoritária Rui Barbosa (cf. MARINHO. Leis inconstitucionais e o poder executivo. Revista de Direito Público - RDP, p. 53).
} 
Naquela época já se entendia que não se pode excluir do controle de constitucionalidade os Poderes Executivo e Legislativo, uma vez que todos os Poderes são obrigados a observar a constitucionalidade das leis, embora a Constituição reserve ao Judiciário a função específica de declarar a inconstitucionalidade e de dar a última palavra na interpretação de qualquer norma jurídica.

Mesmo depois, o Supremo Tribunal Federal manteve esse entendimento, pois o titular exclusivo da representação de inconstitucionalidade, o Procurador-Geral da República, poderia retardá-la ou simplesmente não deflagrá-la. Na vigência das Constituições de 1967/69, firmou-se o entendimento de ser constitucional decreto do chefe do Poder Executivo que determina aos órgãos a ele subordinados a abstenção da execução de dispositivos legais de flagrante inconstitucionalidade (Rp 980/SP. Rel. Min. Moreira Alves. DJ, 19 set. 1980). ${ }^{33}$

A controvérsia doutrinária e jurisprudencial acirrou-se com a Constituição de 1988, que alargou a legitimidade de instauração do controle abstrato de constitucionalidade, na qual incluiu os chefes dos Poderes Executivo federal, estadual e distrital. A possibilidade de liminar em sede de controle abstrato nutriu, outrossim, a tese de que não mais se justificaria o descumprimento administrativo de lei reputada inconstitucional. ${ }^{34}$ Contudo, na ADI-MC 221/DF (Rel. Min. Moreira Alves), julgada em 1990, tal ponto de vista foi expressamente rechaçado e preservada a antiga orientação, atualmente defendida, dentre tantos, por Clemerson Mérlin Clève, Luis Roberto Barroso, Gustavo Binenbojm, Alexandre de Moraes $^{35}$ e João Batista Gomes Moreira. ${ }^{36}$

Não obstante, o poder-dever do chefe do Poder Executivo federal, estadual ou distrital de propor ação direta de inconstitucionalidade, aberto pelo novo panorama constitucional, limitou bastante seu direito de resistência ao cumprimento de normas inconstitucionais. É que o dever de

\footnotetext{
32 MENDES. Direitos fundamentais e controle de constitucionalidade: estudos de direito constitucional, p. 325.

${ }^{33} \mathrm{Na}$ doutrina, reforçaram tal juízo: Carlos Alberto Lúcio Bittencourt, Pontes de Miranda, Manuel Gonçalves Ferreira Filho, Mário Masagão (cf. BINENBOJM. A nova jurisdição constitucional brasileira: legitimidade democrática e instrumentos de realização, p. 234) e Hely Lopes Meirelles (Direito administrativo brasileiro, p. 616, 617). Na mão oposta: Josaphat Marinho (Leis inconstitucionais e o poder executivo. Revista de Direito Público - RDP) e Alfredo Buzaid (cf. VELOSO. Controle jurisdicional de constitucionalidade, p. 320).

34 Nesta linha cita-se: Cármen Lúcia Antunes Rocha, Eros Grau (cf. DUTRA JÚNIOR. Recusa ao cumprimento, pelo chefe do executivo estadual ou distrital, de lei manifestamente inconstitucional: limites e possibilidades numa perspectiva atual. In: CONGRESSO NACIONAL DE PROCURADORES DE ESTADO, 19., 2003, Aracajú. 15 anos de Constituição: em busca de sua plena efetividade, p. 159-171) e Zeno Veloso (Controle jurisdicional de constitucionalidade, p. 317 et seq.).
} 
proporcionalidade funciona como fundamento e técnica para toda e qualquer decisão dos agentes públicos, ${ }^{37}$ exigindo que os Poderes Públicos escolham, para a realização de seus fins, meios adequados, necessários e proporcionais. Legitimados ativos do controle abstrato de constitucionalidade, o Presidente da República e os Governadores têm agora à disposição meio mais adequado, em tese, para evitar a aplicação de norma inconstitucional. A ação direta de inconstitucionalidade é menos gravosa porque prestigia a harmonia entre os Poderes e dispensa o simples descumprimento da norma inconstitucional. Mas apenas em princípio, porque, em determinadas situações urgentes, o direito de resistência é o único meio adequado e, portanto, necessário de se evitar a concretização de inconstitucionalidades. Obtempera José Dutra Júnior:

Nesse caso, a recusa ao cumprimento da lei só é sustentável se o cumprimento imediato da norma puder gerar danos irreparáveis ao ente público, e desde que, de imediato, seja ajuizada a ação direta, justificando-se a não-aplicação da lei enquanto não sobrevier decisão do STF sobre o pedido cautelar. ${ }^{38}$

Vale lembrar que o raciocínio acima exposto só é válido para o Presidente da República e os Governadores de Estado e do Distrito Federal, quando em face de atos normativos suscetíveis de fiscalização em abstrato de constitucionalidade, quais sejam: os complexos normativos genéricos e abstratos vigentes, federais e estaduais ou distritais isomorfos, com fundamento de validade direto na Constituição e supervenientes aos parâmetros de constitucionalidade.

Os Prefeitos não têm acesso ao controle abstrato de constitucionalidade. Inadequada a via judicial, o direito de resistência é o único meio disponível. Curioso que até outros Chefes de Poderes e de órgãos independentes estão em idêntica situação, à vista do art. 103 da Constituição da República. Por exemplo, os Presidentes das Casas Legislativas, dos Tribunais de Justiça e das Cortes de Contas. Até mesmo o Presidente do Supremo Tribunal Federal, no exercício de suas funções administrativas, pode se deparar com uma norma inconstitucional que lhe imponha alguma

\footnotetext{
${ }^{35}$ Cf. BINENBOJM, Gustavo. A nova jurisdição constitucional brasileira: legitimidade democrática e instrumentos de realização, p. 233, 234.

${ }^{36}$ MOREIRA. Direito administrativo: da rigidez autoritária à flexibilidade democrática, p. 410 e 411.

${ }^{37}$ BINENBOJM, Gustavo. Da supremacia do interesse público ao dever de proporcionalidade: um novo paradigma para o direito administrativo. Revista Brasileira de Direito Público - RBDP, p. 77-113.

${ }^{38}$ DUTRA JÚNIOR. Recusa ao cumprimento, pelo chefe do executivo estadual ou distrital, de lei manifestamente inconstitucional: limites e possibilidades numa perspectiva atual. In: CONGRESSO NACIONAL DE PROCURADORES DE ESTADO, 19., 2003, Aracajú. 15 anos de Constituição: em busca de sua plena efetividade, p. 163.
}

A \& C R. de Dir. Administrativo e Constitucional, Belo Horizonte, ano 7, n. 28, p. 45-75, abr./jun. 2007 
obrigação. Como não está no exercício do ofício jurisdicional, não pode declarar a inconstitucionalidade em concreto da norma para se livrar do seu cumprimento. Mas pode, fundamentadamente, deixar de aplicar essa norma e lançar mão de outra melhor. Tem competência, inclusive, para ordenar que os subordinados administrativos façam o mesmo. Cumpre, por esse meio adequado, seu dever de proporcionalidade e controle administrativo de constitucionalidade sobre o ato, não dispondo diretamente de outro meio, pois não pode instaurar de ofício controle judicial de constitucionalidade sobre a norma.

Os Presidentes do Senado, da Câmara dos Deputados e das Assembléias Legislativas e da Câmara Legislativa do Distrito Federal dependem das Mesas das respectivas Casas para deflagração do controle abstrato de constitucionalidade. Os Presidentes dos Tribunais de Contas ${ }^{39}$ e das Câmaras Municipais nem essa alternativa têm.

Por sua vez, o Procurador-Geral da República sempre pôde instaurar o controle de constitucionalidade da norma. Então, sua condição se afasta da do Presidente do Supremo Tribunal Federal e se assemelha à do Presidente da República e dos Governadores. Só pode deixar de cumprir a lei inconstitucional ou determinar que seus subordinados administrativos não a apliquem, se a ação direta não for adequada à urgência do caso. A situação dos Procuradores-Gerais de Justiça é ainda mais peculiar, porque eles têm acesso direto somente ao controle abstrato de constitucionalidade estadual.

Por outro prisma, não era sindicável em abstrato a validade de normas como as pré-constitucionais, as municipais ou distritais equivalentes e as leis de efeitos concretos. Se contrariassem a Constituição, só restava aos Chefes dos Poderes e dos órgãos independentes a alternativa de não aplicá-las, privilegiando as normas constitucionais e as infraconstitucionais válidas.

Atualmente, adverte José Dutra Júnior, é necessário atentar para a viabilidade de argüição de descumprimento de preceito fundamental (ADPF). Um dos objetivos desta é exatamente evitar lesão, resultante de ato do Poder Público, a preceito fundamental. Sua decisão de mérito tem eficácia contra todos e efeito vinculante relativamente aos demais órgãos do Poder Público, com possibilidade de concessão de liminar

\footnotetext{
39 Por outro lado, segundo a Súmula n 347 do STF, os Tribunais de Contas podem, no estrito exercício de suas funções técnicas, apreciar a constitucionalidade de leis e atos normativos do Poder Público.
} 
(Lei $\mathrm{n}^{\circ} 9.882 / 99$, art. $1^{\circ}, 5^{\circ}$ e 10$)$. Só que sua legitimidade ativa é a mesma da ação direta de constitucionalidade, não sendo, então, meio adequado posto diretamente à disposição dos Presidentes dos Poderes Legislativo e Judiciário, nem dos Procuradores-Gerais de Justiça e Prefeitos. Mesmo para os legitimados existem restrições ao seu manejo, em vista do seu caráter subsidiário perante os outros meios judiciais eficazes (Lei $\mathrm{n}^{\mathrm{o}}$ $9.882 / 99$, art. $\left.4^{\circ}, \S 1^{\circ}\right)$. Ademais, seus requisitos carecem de especial atenção, a começar pela existência de lesão atual ou eminente, que impõe a comprovação de concreta violação a preceito constitucional considerado fundamental.

É bem verdade, o legislador poderia ter considerado a lesão em seu aspecto abstrato. Porém, essa não é a interpretação mais adequada, pois só a exigência de concreta lesão parece justificar a eleição de "prova" da violação de preceito fundamental como requisito da petição inicial (inciso III do art. $3^{\circ}$ da Lei n. 9.882/99). ${ }^{40}$

A questão constitucional também precisa ser relevante. Não é qualquer uma que justifica a autuação do Supremo Tribunal Federal. Finalmente, conquanto trabalhe a ADPF com a noção de descumprimento cuja compreensão é mais ampla do que a de inconstitucionalidade, o aspecto material do parâmetro de controle é mais restrito, abrangendo somente preceitos fundamentais.

Por todo o exposto, parece possível aos Chefes de Poderes e dos órgãos independentes deixarem de aplicar leis inconstitucionais e determinar às respectivas Administrações Públicas chefiadas que também deixem de aplicá-las, optando por privilegiar as normas constitucionais e infraconstitucionais válidas. Poder-se-ia questionar, como Aragón, a parcialidade desse tipo de decisão dos mencionados agentes públicos e o conseqüente reconhecimento de um controle político dos atos administrativos, inadmissível quando afronta a vontade do legislador, plasmada nas normas legais em sentido estrito. No nosso sistema, um controle interno apto a esquivar das normas legais inconstitucionais só pode ser jurídico. E, para tanto, requer uma advocacia pública forte o suficiente para fundamentar com imparcialidade a inaplicabilidade administrativa de normas inconstitucionais. Nesse sentido, é de suma importância a unicidade de instituição de advocacia pública em cada órbita federativa,

${ }^{40}$ BERNARDES. Controle abstrato de constitucionalidade: elementos materiais e princípios processuais, p. 100.

A \& C R. de Dir. Administrativo e Constitucional, Belo Horizonte, ano 7, n. 28, p. 45-75, abr./jun. 2007 
pois a pulverização institucional fraqueja-a. Dessa feita, critica-se a restrição das funções de consultoria e assessoramento jurídico da AGU ao Poder Executivo, possibilitando aos demais Poderes e ao Ministério Público constituírem suas próprias assessorias jurídicas, em prejuízo da independência e imparcialidade questionadas por Aragón. Melhor trilhou o constituinte acerca da advocacia pública estadual e distrital, não limitando ao Poder Executivo a consultoria jurídica das Procuradorias-Gerais de Estado e do Distrito Federal, apesar de falhar ao silenciar sobre o assessoramento jurídico. Pior foi a omissão sobre a advocacia pública na esfera municipal, prejudicando seriamente o exercício do controle jurídico interno. Mesmo aceitando os ensinamentos de Häberle sobre a sociedade aberta dos intérpretes da Constituição, é visível que a interpretação empreendida pelos alcaides não opera sob racionalidade jurídica e, ainda que seja bacharel em direito ou advogado, seria proposital ou inconscientemente tendenciosa.

A advocacia pública é função constitucionalmente essencial à Justiça e, se corretamente organizada, possibilita o pleno controle jurídico interno de constitucionalidade, livrando os Chefes de Poderes e órgãos independentes do fado da parcialidade e legitimando-os a ordenar aos seus subordinados a aplicação direta da Constituição ou de alguma outra norma infraconstitucional válida no lugar da inconstitucional. Destaca Marcos Juruena Villela Souto que a interpretação jurídica final no âmbito da Administração e seu conseqüente controle interno precisam ser técnicos, neutros, apolíticos, imparciais e acima das lides partidárias. ${ }^{41}$

Ainda assim, respeitável doutrina entende que o Chefe do Poder Executivo não pode deixar de cumprir nenhuma lei, mesmo as evidentemente inconstitucionais. Opinião que, concatenada com o exposto nos parágrafos anteriores, apresenta o saldo de que os Chefes dos demais Poderes e dos órgãos independentes, quando no exercício de atípica função executiva, estão obrigados a aplicar leis inconstitucionais. Objetivando repelir ou, ao menos, encurtar o campo de incidência dessa segunda corrente doutrinária, serão estudadas a seguir as antinomias normativas, em especial as que resultam do embate entre normas legais e constitucionais, e as técnicas para superá-las. Com isso, pretende-se oferecer outros meios de se evitar a aplicação de normas inconstitucionais e restringir a solução simplista do descumprimento de lei somente para certos casos em

${ }^{41}$ SOUTO. O papel da advocacia pública no controle da legalidade da administração. Interesse Público, p. $48-49$.

A \& C R. de Dir. Administrativo e Constitucional, Belo Horizonte, ano 7, n. 28, p. 45-75, abr./jun. 2007 
que se afigurar inevitável.

\subsection{Antinomias normativas e sua superação pela Administração Pública}

Antes e a fim de facilitar o estudo das antinomias, é bom recordar a distinção entre disposição textual e norma. Esta é o conteúdo normativo daquela e sempre resulta do trabalho de interpretação. Disposição é o enunciado lingüístico emanado do trabalho de produção do direito objetivo; norma é o conteúdo de sentido resultante da interpretação da disposição. Habitualmente, a cada disposição corresponde uma norma, caso em que é indiferente a distinção entre uma e outra. A questão ganha relevo nas seguintes situações: (i) norma sem disposição, como as implícitas e as consuetudinárias; (ii) disposição sem norma, v.g. art. 17 da lei de ação civil pública; (iii) pluralidade de disposições que ensejam uma única norma; e (iv) pluralidade de normas extraídas de uma mesma disposição. No último caso há o seguinte desdobramento: (iv-a) de disposição polissêmica ou ambígua da qual defluem normas antagônicas entre si, caso em que a opção por aplicar uma exclui a aplicação da(s) outra(s); (iv-b) disposição complexa da qual se obtêm duas ou mais normas parciais, cuja soma exaure o significado do enunciado textual. ${ }^{42}$

Os advogados públicos devem esclarecer ao gestor público todas essas possibilidades, a fim de se evitar o desnecessário descumprimento de norma legal, pois, muitas vezes, a disposição legal abriga várias normas, sendo possível a aplicação de uma que não agrida a Constituição. Tal procedimento deixa claro que as eventuais contradições entre a Constituição e as leis não podem ser analisadas no limitado plano das disposições, mas no das normas delas extraíveis. Insiste Riccardo Guastini que a antinomia é um conflito entre normas e não entre disposições. ${ }^{43}$ Portanto, adota-se neste trabalho a expressão antinomias normativas.

Segundo Luis Prieto Sanchis, existe uma antinomia ou contradição normativa quando, dentro de um mesmo sistema jurídico, se imputam conseqüências incompatíveis às mesmas circunstâncias fáticas. Em outras palavras, quando na presença de um certo comportamento ou situação de fato encontram-se diferentes determinações normativas que não podem ser

\footnotetext{
42 BERNARDES. Controle abstrato de constitucionalidade: elementos materiais e princípios processuais, p. 163 et seq.

${ }^{43}$ GUASTINI. Antinomias y lagunas. Jurídica. Anuario del Departamento de Derecho de la Universidad Iberoamericana, p. 437-450.
}

A \& C R. de Dir. Administrativo e Constitucional, Belo Horizonte, ano 7, n. 28, p. 45-75, abr./jun. 2007 
observadas simultaneamente. Por exemplo, uma norma proíbe o que outra ordena. Não obstante a ficção da unidade e coerência do ordenamento jurídico, é comum deparar-se com antinomias, porque são uma conseqüência natural do dinamismo dos sistemas jurídicos e de um certo déficit de racionalidade do legislador. ${ }^{44}$ Abrindo um parêntese, a coerência do ordenamento jurídico é dada e garantida pela Constituição.

Tradicionalmente, na resolução das antinomias são adotados os seguintes critérios: (i) hierárquico (lex superior derogat inferiori); (ii) cronológico (lex posterior derogat priori); e (iii) da especialidade (lex specialis derogat generale). Apresentam-se duas ressalvas quanto aos brocados latinos: primeira, o termo lex deve atualmente ser entendido como norma; segunda, o vocábulo derogat (derroga) serve somente para o critério cronológico e quando o caso não for de ab-rogação. No critério hierárquico, o que a norma superior faz é invalidar a inferior. O critério da especialidade atua em plano distinto, o da aplicabilidade, só se podendo falar propriamente em derrogação quando a norma especial é posterior à geral, revogando parte do âmbito de incidência desta, ou quando uma norma é sucedida por outra mais geral, de modo que a primeira, revogada em parte, ganha funcionalidade especial em relação à segunda. ${ }^{45}$ Todavia, estar-se-á adotando sempre o critério cronológico.

A objeção apresentada pela doutrina contrária ao direito de resistência é a de que a Administração Pública não pode utilizar o critério hierárquico para solucionar as antinomias entre as normas legais e constitucionais, porque subverte a presunção de validade das leis, só sindicável repressivamente, entre nós, pelo Poder Judiciário, no desempenho de sua precípua função jurisdicional, momento em que pode exercer o controle de constitucionalidade dos atos normativos. ${ }^{46}$

Nesse ponto, cabe destacar que o gestor público pode perfeitamente lançar mão do critério cronológico. Se uma antiga norma legal dispõe em determinado sentido e surge uma nova norma constitucional dispondo em sentido antinômico, deve o Administrador aplicar a segunda, pois a primeira foi revogada. Pairando alguma dúvida, basta consultar a instituição de advocacia pública. É o meio mais adequado de se evitar a prática de atos administrativos inconstitucionais, até porque o Supremo

\footnotetext{
44 PRIETO SANCHÍS. Observaciones sobre las antinomias y el criterio de ponderación. Diritto \& questioni pubbliche, p. 97-114.

${ }_{45}$ Parte da doutrina não aceita essa solução, visualizando a ab-rogação da norma especial pela nova que regula inteiramente a matéria, salvo disposição expressa em sentido contrário (cf. GUASTINI. Antinomias y lagunas. Jurídica. Anuario del Departamento de Derecho de la Universidad Iberoamericana, p. 444).
} 
Tribunal Federal também entende que, em casos tais, não há controle de constitucionalidade, resumindo-se a discussão à mera verificação de recepção ou revogação. A simples possibilidade, em tese, de se argüir descumprimento de preceito fundamental não impede a Administração Pública de interpretar a Constituição e constatar a revogação de certas leis. E, na prática, a viabilidade da ADPF cintila exatamente na hipótese contrária, ou seja, se o Poder Público concluir, administrativamente, que a norma legal não foi revogada pela constitucional e os cidadãos sentirem com isso lesão a preceito fundamental. $\mathrm{O}$ mesmo vale para o viés cronológico do critério da especialidade, na hipótese de uma nova norma constitucional ser contrária a algum ponto específico do âmbito de incidência da norma legal preexistente.

Por fim, restam as antinomias solucionáveis apenas pelo critério hierárquico. Acontece que, em muitos casos, a própria antinomia poderia ser previamente evitada. Relembrando, a antinomia é um conflito entre normas e não entre disposições. Com isso, Guastini quis dizer que: (i) uma antinomia pode, em muitos casos, ser evitada por meio da interpretação; (ii) uma antinomia pode ser criada pela interpretação; (iii) uma antinomia só se apresenta com uma interpretação já realizada; e (iv) que, em conseqüência, a antinomia abre não um problema interpretativo, senão uma questão de outra natureza, não solucionável pela interpretação, mas pela eliminação de uma das normas em conflito. ${ }^{47}$

Se os agentes públicos são contumazes na hipótese (ii), o papel dos advogados públicos é exatamente o de tangenciar, na medida do possível, pela proposição (i). Só se inevitável a antinomia (iii), estar-se-á perante um caso de controle de validade da norma legal (iv), ponto na qual reside a divergência doutrinária dos que não aceitam o direito de resistência administrativa às leis inconstitucionais.

Assim, ao lado das aludidas técnicas de solução de antinomias, existem também procedimentos interpretativos preventivos de antinomias. Guastini menciona a interpretação conforme a Constituição e a interpretação restritiva. A primeira é extremamente útil quando, de uma única disposição legal, podem ser extraídas várias normas. Nos casos mais difíceis, é dever das instituições de advocacia pública identificar e descartar as

\footnotetext{
${ }^{46}$ Os Tribunais de Conta também podem, no estrito exercício de sua atividade fim, fiscalizar a validade de atos legislativos (Súmula nº 347 do STF).

${ }^{47}$ GUASTINI. Antinomias y lagunas. Jurídica. Anuario del Departamento de Derecho de la Universidad Iberoamericana, p. 437, 438.
}

A \& C R. de Dir. Administrativo e Constitucional, Belo Horizonte, ano 7, n. 28, p. 45-75, abr./jun. 2007 
que afrontam o sistema constitucional e apresentar aos agentes públicos para aplicação somente as adequadas à Constituição. Atendida a vontade (se bem que confusa) do legislador, não há que se falar em descumprimento de lei e vituperação da divisão de Poderes.

A circunstância de se eliminarem alguns sentidos inválidos de uma disposição, para acomodá-la a determinada situação, não implica necessariamente a realização de controle de constitucionalidade.

(...) o que aí ocorre é a simples resolução de embate sobre qual norma - entre aquelas que podem ser obtidas - se deve aplicar concretamente, motivo pelo qual a decisão a respeito não foge dos limites da própria interpretação da disposição polissêmica. (...), considerando que da disposição se pode obter alguma norma válida para incidir na hipótese, não há falar em disputa entre a norma infraconstitucional aplicável e a norma constitucional paramétrica.

(...) todos que aplicam normas infraconstitucionais têm por obrigação dar a elas o sentido constitucionalmente adequado. Desse modo, a interpretação conforme a constituição, quando voltada à identificação da norma concretamente aplicável (tarefa que pode ser empreendida por qualquer um), não se resume só aos mecanismos de controle de constitucionalidade. ${ }^{48}$

A interpretação restritiva tem o efeito de excluir do campo de aplicação de uma norma uma determinada hipótese fática que seria alcançada pela interpretação literal. Isso, contudo, pode levar a resultados semelhantes aos da técnica de declaração de inconstitucionalidade sem redução de texto, que, segundo Gilmar Mendes, não se confunde com a interpretação conforme, uma vez que declara a norma inconstitucional em relação a determinadas situações expressamente indicadas pelo Tribunal. ${ }^{49}$ Daí, poder-se-ia objetar a interpretação restritiva da Administração Pública como descumprimento disfarçado da lei. Todavia, em última análise, tal objeção significaria negar a existência do poder regulamentar dos Chefes de Poder Executivo de expedir normas complementares à lei, para sua fiel execução. "O regulamento é um dever do Chefe do Poder executivo para explicitar o conteúdo da lei, para tratar sobre a sua execução, ou até mesmo interpretar as disposições legais". ${ }^{50}$

Dessa feita, a controvérsia sobre o direito de resistência restringese às hipóteses em que a única ou todas as normas extraíveis da disposição legal apresenta(m) inconstitucionalidade total ou parcial cuja declaração requeira redução do texto.

\footnotetext{
${ }^{48}$ BERNARDES. Controle abstrato de constitucionalidade: elementos materiais e princípios processuais, p. 335,336 .
}

A \& C R. de Dir. Administrativo e Constitucional, Belo Horizonte, ano 7, n. 28, p. 45-75, abr.jun. 2007 
Finalmente, cumpre esclarecer que nem todas as antinomias entre normas constitucionais e legais conduzem à invalidade destas. Tal só ocorre nas antinomias em abstrato, também chamadas de necessárias, inevitáveis ou internas, que se verificam quando duas ou mais normas atribuem conseqüências jurídicas incompatíveis a hipóteses fáticas abstratas sobrepostas no todo ou em parte. Podem ser identificadas abstratamente através da simples interpretação da lei, sem necessidade da inferência a um caso concreto. Os pressupostos fáticos descritos pelas normas se sobrepõem de forma tal que sempre que se pretender aplicar uma delas surgirá o conflito com a outra. Já as antinomias em concreto, contingentes, acidentais ou externas, só são identificáveis no momento de aplicação das normas, quando se verifica que elas atribuem conseqüências jurídicas incompatíveis a um mesmo e determinado caso concreto. Não é possível visualizar de antemão todas as hipóteses de antinomia em concreto. A solução só é alcançável à vista de cada caso, momento em que se justifica a escolha de uma norma, opção que pode ser diferente das de outros casos (derrotabilidade de normas jurídicas - defeasibility). ${ }^{51}$ Afirma Guastini que as antinomias em abstrato dependem da estrutura da linguagem legislativa, ao passo que as antinomias em concreto dependem da estrutura do mundo. ${ }^{52} \mathrm{O}$ seguinte julgado é elucidativo:

RECURSO JEF $\mathrm{n}^{\mathrm{o}}$ : 200535007164388; ORIGEM: $14^{\mathrm{a}}$ VARA - 2004.35.00. 722908-0; CLASSE: 71200; RELATOR(A): ABEL CARDOSO MORAIS.

EMENTA: BENEFÍCIO DE PRESTAÇÃO CONTINUADADA. LOAS. RENDA PER CAPITA. NECESSIDADE DE SE CONTRAPÔR A REGRA LEGAL EM FACE DE TODAS AS CIRCUNSTÂNCIAS DO CASO. ANTINOMIA EM ABSTRATO VS. ANTINOMIA EM CONCRETO. "DERROTABILIDADE" DO $\S 3^{\circ}$ DO ART. 20 DA LEI 8.742/93.

1. Embora o STF já tenha reconhecido a constitucionalidade em tese do $\S 3^{\circ}$ do art. 20 da Lei 8.742/93, o requisito da renda mensal per capita inferior a 1/4 (um quarto) do salário mínimo, consideradas todas as circunstâncias do caso, pode apresentar antinomia concreta em face de algum princípio constitucional ou regra implícita deste decorrente.

2. O reconhecimento dessa antinomia concreta gera a "derrotabilidade" (defeasibility) da regra legal, mas não viola a autoridade da decisão do STF proferida na ADIn 1.232/DF.

\footnotetext{
${ }^{49}$ MENDES. Jurisdição constitucional: o controle abstrato de normas no Brasil e na Alemanha, p. 232 et seq.

50 BITTENCOURT. Manual de direito administrativo, p. 40.

51 PRIETO SANCHÍS. Observaciones sobre las antinomias y el criterio de ponderación. Diritto \& questioni pubbliche, p. 99.

${ }^{52}$ GUASTINI. Estudios de teoría constitucional, p. 143.
}

A \& C R. de Dir. Administrativo e Constitucional, Belo Horizonte, ano 7, n. 28, p. 45-75, abr./jun. 2007 
3. Quando se resolve uma antinomia em abstrato, considera-se a norma desprezada, para todas as demais hipóteses em que norma se aplicaria porque: (a) inválida (em caso de conflito hierárquico); ou (b) sem vigência (conflito cronológico); ou (c) ineficaz (conflito da especialidade). Diferentemente, a resolução de uma antinomia em concreto não implica qualquer juízo de invalidação da norma que se deixou de aplicar, a qual segue válida, vigente e eficaz para se aplicar a outras situações.

4. Não bastasse, a decisão de mérito da ADIn 1.232/DF tampouco dispõe de efeitos vinculantes, já que proferida antes da edição da Lei 9.868/99.

5. Comprovados gastos com medicamentos necessários à manutenção da pessoa que necessita do amparo constitucional, deve ser diminuída, em iguais proporções, a base de cálculo da renda mensal per capita.

6. Recurso desprovido. Sentença confirmada.

ACÓRDÃO: VISTOS, relatados e discutidos os autos, à unanimidade, ACORDAM os Juízes da Turma Recursal dos Juizados Especiais Federais da Seção Judiciária do Estado de Goiás em NEGAR PROVIMENTO ao recurso, nos termos do voto do Juiz-Relator. Goiânia, 14 de dezembro de 2005. Juiz JULIANO TAVEIRA BERNARDES (Relator Suplente).

$\mathrm{O}$ voto do relator suplente frisou os seguintes pontos:

(...) o reconhecimento da constitucionalidade da norma não impede que a aplicação concreta dela possa ensejar distorções que comprometam a integridade e a coerência do sistema jurídico. E caso isso ocorra, o intérprete há de buscar a adequada interpretação da norma, de modo a contornar esses eventuais efeitos nocivos que a interpretação literal da disposição poderia trazer à incolumidade do sistema jurídico no qual se insere.

Na verdade, o ponto remete à importantíssima discussão acerca das diferenças entre antinomia em abstrato e antinomia em concreto (GÜNTHER). Sobre o assunto, sabe-se que antinomia em abstrato é aquela que se configura sempre que se verifique a superposição das hipóteses de incidência previstas em normas distintas, de tal forma que, quando se pretenda aplicar uma dessas normas, já se percebe, num plano de análise dissociado da aplicação fática, a incompatibilidade de soluções normativas entre pelo menos duas delas. Por exemplo: uma norma proíbe o aborto e outra admite o aborto terapêutico. De seu turno, antinomia em concreto (ou contingente) é a que somente se manifesta diante de situações concretas, em face das quais não é possível antever abstratamente o conflito entre normas distintas, dada a inviabilidade de se predeterminar a total extensão da faixa de superposição dos respectivos supostos fáticos a que estas se apliquem. Para ilustrar, tanto PRIETO SANCHÍS quanto GÜNTHER aludem à norma que determina o cumprimento das promessas feitas e a que determina ajudar ao próximo em caso de necessidade. Embora em tese não haja conflito entre tais normas - isto é, as normas não prevêem soluções teoricamente incompatíveis entre si -, alguém poderá deparar-se com a necessidade de ajudar a um acidentado, mesmo se antes prometera comparecer a uma entrevista no mesmo horário.

Bem se vê, as antinomias em abstrato manifestam-se no plano da validade (ou da vigência) das normas em conflito (segundo GÜNTHER, no "discurso da 
validez"), enquanto as antinomias em concreto aparecem no durante o "discurso da aplicação". Significa dizer, a solução de uma antinomia em concreto não implica juízo de invalidação da norma que se deixou de aplicar, pois esta segue válida (ou vigente) para regular outras situações; já a resolução de uma antinomia em abstrato importa em considerar a norma desprezada inválida (em caso de conflito hierárquico), sem vigência (conflito cronológico) ou ineficaz (conflito da especialidade) para todas as outras hipóteses.

A questão remete também ao problema da "derrotabilidade" das normas.

Assunto pouco enfrentado no direito brasileiro, o fenômeno da "derrotabilidade" tem a ver com a inaplicação, total ou parcial, de certa regra jurídica, muito embora se confirme a exteriorização dos pressupostos a partir dos quais se deveria normalmente aplicar a regra. Conforme ensina PABLO NAVARRO, como o legislador não pode prever as infinitas circunstâncias que irão aparecer no futuro, as regulações normativas estão abertas a exceções que "derrotam" a qualificação jurídica inicialmente proposta pela autoridade normativa. Certo, algumas vezes, essas exceções são expressamente introduzidas no contexto regulatório pelo próprio legislador, mas, em outras ocasiões, tais exceções estão implícitas no ordenamento jurídico, razão por que devem ser identificadas no momento da aplicação das normas. Assim, para HART, somente seria possível enumerar as condições normais de aplicação dos conceitos jurídicos, razão por que devem tais condições ser acompanhadas de uma cláusula aberta (“a menos que...").

(...)

Mesmo uma regra cuja constitucionalidade tenha sido reconhecida pelo STF pode deixar de ser aplicada concretamente, quando, consideradas todas as circunstâncias do caso (all things considered), no lugar dela, deva preponderar a aplicação de regra de exceção (implícita ou explícita) decorrente da concretização de princípio constitucional contraposto ao que lhe dá fundamento.

Segundo a doutrina que nega o direito de resistência, a Administração Pública não pode utilizar o critério hierárquico para solucionar as antinomias entre normas legais e constitucionais. Contudo, foi demonstrado acima que as antinomias em concreto envolvem um juízo de mera aplicabilidade das normas e que, portanto, devem ser resolvidas no exercício do controle interno de constitucionalidade dos atos administrativos.

É fenômeno da percepção recente que uma regra pode ser perfeitamente constitucional, do ponto de vista abstrato e, no entanto, em certas circunstâncias, produzir resultado inconstitucional, por violar o próprio fim que busca alcançar. Há certos fatos que só na aparência se ajustam à disposição legal. A lei existe para o que normalmente acontece, de modo que pode ser afastada sua incidência sobre situações fora do comum. ${ }^{53}$

Então, mesmo quem discorda do descumprimento administrativo de lei inconstitucional deve admitir que a Administração está impedida de resolver tão-somente as antinomias em abstrato, nas quais a única ou 
todas as normas extraíveis da disposição legal apresenta(m) inconstitucionalidade total ou parcial com necessidade de redução do texto. Só nesses casos se poderia alegar o deslocamento indevido do controle de constitucionalidade e validade das normas legais para a Administração Pública.

\section{Conclusões}

Na construção do Estado Democrático e Social de Direito, o controle interno de constitucionalidade precisa ser jurídico, ou seja, trabalhar com parâmetros normativos objetivos e indisponíveis, o que coincide com as atribuições dos advogados públicos. Todavia, para ser verdadeiramente jurídico o controle, é imprescindível dotar a advocacia pública de garantias e prerrogativas que proporcionem a objetividade, imparcialidade e independência necessárias ao exercício dessa Função Essencial à Justiça.

O controle interno de constitucionalidade pode culminar com o descumprimento administrativo da lei flagrantemente inconstitucional pelo Chefe de Poder ou de órgão independente, nos casos emergenciais, antes do julgamento da medida liminar em sede de controle abstrato de constitucionalidade. Essa medida drástica só é adequada para as antinomias em abstrato nas quais a única ou todas as normas extraíveis da disposição legal apresenta(m) inconstitucionalidade total ou parcial com necessidade de redução do texto. As antinomias em concreto devem ser solucionadas caso a caso por meio da interpretação jurídica dos advogados públicos. As antinomias em abstrato nas quais a inconstitucionalidade possa ser declarada sem redução de texto comportam interpretação restritiva do Poder Público, com o auxílio da advocacia pública, e solução genérica pelo Poder Regulamentar do Chefe do Poder Executivo. Nos demais casos, as antinomias devem ser evitadas através da interpretação conforme a Constituição, buscando-se a norma adequada ao sistema constitucional.

\section{Referências}

AMARAL, Rafael Caiado. Breves ensaios acerca da hermenêutica constitucional de Peter Häberle. Jus Navigandi, Teresina, ano 7, n. 64, abr. 2003. Disponível em: < http://www1.jus. com.br/doutrina/texto.asp?id=3995 >. Acesso em: 21 jul. 2005.

ARAGÓN, Manuel. Constitución, democracia y control. México: Universidad Nacional Autónoma de México, 2002. Disponível em: < http://www.bibliojuridica.org/libros/libro.

${ }^{53}$ MOREIRA. Direito administrativo: da rigidez autoritária à flexibilidade democrática, p. 410. 
htm?l=288>. Acesso em: 21 jul. 2006.

ÁVILA, Humberto. Teoria dos princípios: da definição à aplicação dos princípios jurídicos. 4. ed., 3. tir. São Paulo: Malheiros, 2005.

BARROSO, Luís Roberto. Fundamentos teóricos e filosóficos do novo direito constitucional brasileiro (Pós-modernidade, teoria crítica e pós-positivismo). Revista Diálogo Jurídico, Salvador, CAJ - Centro de Atualização Jurídica, v. 1, n. 6, set. 2001. Disponível em: < http:// www.direitopublico.com.br>. Acesso em: 20 de maio de 2004.

BARROSO, Luís Roberto. O direito constitucional e a efetividade de suas normas: limites e possibilidades da Constituição brasileira. 4. ed. Rio de Janeiro: Renovar, 2000.

BERNARDES, Juliano Taveira. Controle abstrato de constitucionalidade: elementos materiais e princípios processuais. São Paulo: Saraiva, 2004.

BINENBOJM, Gustavo. Da supremacia do interesse público ao dever de proporcionalidade: um novo paradigma para o direito administrativo. Revista Brasileira de Direito Público - RBDP, Belo Horizonte, ano 3, n. 8, p. 77-113, jan./mar. 2005.

BINENBOJM, Gustavo. A nova jurisdição constitucional brasileira: legitimidade democrática e instrumentos de realização. 2. ed. Rio de Janeiro: Renovar, 2004.

BITTENCOURT, Marcus Vinicius Corrêa. Manual de direito administrativo. Belo Horizonte: Fórum, 2005.

BONAVIDES, Paulo. Do Estado liberal ao Estado social. 6. ed. São Paulo: Malheiros, 1996.

CAnotilho, J. J. Gomes. Direito constitucional e Teoria da Constituição. 4. ed. Coimbra: Almedina, 2000.

CARVALHO, Kildare Gonçalves. Direito constitucional. 10. ed. Belo Horizonte: Del Rey, 2004.

CASTRO, Caterine Vasconcelos de; ARAÚJO, Francisca Rosileide de Oliveira; TRINDADE, Luciano José. A advocacia pública no estado democrático de direito: reflexões jurídicas acerca dessa instituição estatal essencial à justiça. Revista da Procuradoria Geral do Estado do Acre, Rio Branco, n. 3, p. 213-253, jan./dez. 2003. Disponível em: <http://www.pge.ac.gov. br/biblioteca/revista/revista3/revista\%203.htm > . Acesso em: 22 jul. 2006.

CORDARO, César Antonio Alves. A advocacia pública e os municípios. Revista Trimestral de Advocacia Pública, ano 3, n. 5. p. 12-13, maio 1997. Disponível em: < http://members. tripod.com/ ibap/artigos/caacl.htm>. Acesso em: 8 jul. 2006.

DI PIETRO, Maria Sylvia Zanella. Inovações no direito administrativo brasileiro. Interesse Público, Porto Alegre, ano 6, n. 30, p. 39-58, mar./abr. 2005.

DUTRA JÚNIOR, José. Recusa ao cumprimento, pelo chefe do executivo estadual ou distrital, de lei manifestamente inconstitucional: limites e possibilidades numa perspectiva atual. In: CONGRESSO NACIONAL DE PROCURADORES DE ESTADO, 19., 2003, Aracajú. 15 anos de Constituição: em busca de sua plena efetividade. Aracajú: J. Andrade, 2003. v. 1, p. 159-171.

FERREIRA, Olavo Augusto Vianna Alves; FARIA, Ana Paula Andrade Borges de. A independência e a autonomia funcional do Procurador do Estado. Jus Navigandi, Teresina, ano 6, n. 53, jan. 2002. Disponível em: < http://www1.jus.com.br/doutrina/texto.asp?id= 2527>. Acesso em: 21 abr. 2004.

FIGUEIREDO, Lúcia Valle. Competência dos tribunais administrativos para controle da constitucionalidade. Interesse Público, Porto Alegre, ano 6. n. 24, p. 24-28, mar./abr. 2004. 
GRANDE JÚNIOR, Cláudio. A advocacia pública no Estado democrático de direito. Doutrina $A D C O A S$, Rio de Janeiro, ano 7, n. 23, p. 450-451, 1. quinzena dez. 2004.

GRANDE JÚNIOR, Cláudio. A advocacia pública no Estado democrático de direito. $O$ Estado do Paraná, Curitiba, 27 jun. 2004. Caderno Direito e Justiça.

GRANDE JÚNIOR, Cláudio. O controle interno de constitucionalidade exercido pelas procuradorias-gerais dos Estados e do Distrito Federal. In: CONGRESSO NACIONAL DE PROCURADORES DE ESTADO, 31, 2005, Florianópolis. As perspectivas da advocacia pública e a nova ordem econômica. Florianópolis: OAB/SC, 2006. p. 239-272.

GRANDE JÚNIOR, Cláudio. O controle interno de constitucionalidade exercido pelas Procuradorias-Gerais dos Estados e do Distrito Federal. Fórum Administrativo - Direito Público - FA, Belo Horizonte, ano 5, n. 57, p. 6379-6392, nov. 2005.

GRANDE JÚNIOR, Cláudio. O controle interno de constitucionalidade exercido pelas procuradorias-gerais dos Estados e do Distrito Federal. Revista de Doutrina da $4^{a}$ Região, Porto Alegre, ano 2, n. 11, 21 mar. 2006. Disponível em: <http:/www.revista doutrina.trf4.gov.br/index.htm?http://www.revistadoutrina.trf4.gov.br/artigos/edicao011/ claudio_junior.htm>. Acesso em: 5 jun. 2006.

GRANDE JÚNIOR, Cláudio. O estado democrático de direito e a incipiente advocacia pública brasileira. Revista do Tribunal Regional Federal - Primeira Região, Brasília, v. 16, n. 12, p. 15-26, dez. 2004.

GRANDE JÚNIOR, Cláudio. O Estado Democrático de Direito e a incipiente advocacia pública brasileira. Jus Navigandi, Teresina, ano 8, n. 400, 11 ago. 2004. Disponível em: $<$ http://www1.jus.com.br/doutrina/texto.asp?id=5580>. Acesso em: 29 jul. 2005.

GUASTINI, Riccardo. Estudios de teoría constitucional. México: Universidad Nacional Autónoma de México, 2001. Disponível em: <http://www.bibliojuridica.org/libros/libro.htm?l=22>. Acesso em: 26 jun. 2006.

GUASTINI, Riccardo. Antinomias y lagunas. Jurídica. Anuario del Departamento de Derecho de la Universidad Iberoamericana, México, n. 29, p. 437-450, 1999. Disponível em: <http:// www.juridicas.unam.mx/publica/rev/indice.htm?r=jurid\&n=29>. Acesso em: 27 jun. 2006.

GÜNTHER, Klaus. Un concepto normativo de coherencia para una teoría de la argumentación jurídica. Doxa. Cuadernos de Filosofía del Derecho, Alicante, n. 17-18, p. 279-372, 1995. Disponível em: < http://descargas.cervantesvirtual.com/servlet/SirveObras/ doxa/01350518602340617976802/cuaderno17/doxa17_12.pdf. >. Acesso em 27 jun. 2006.

MOREIRA, João Batista Gomes. Direito administrativo: da rigidez autoritária à flexibilidade democrática. Belo Horizonte: Fórum, 2003.

HÄBERLE, Peter. Hermenêutica constitucional: a sociedade aberta dos interpretes da Constituição: contribuição para a interpretação pluralista e procedimental da Constituição. Porto Alegre: Sérgio Antônio Fabris, 1997.

HESSE, Konrad. Elementos de direito constitucional da República Federal da Alemanha. Porto Alegre: Sérgio Antonio Fabris, 1998.

KELSEN, Hans. Teoria pura do direito. 6. ed., 5. tir. São Paulo: Martins Fontes, 2003.

MARINHO, Josaphat. Leis inconstitucionais e o poder executivo. Revista de Direito Público - RDP, São Paulo, ano 17, n. 71, p. 51-59, jul./set. 1984.

MASSA, Patrícia Helena. O papel do advogado público na administração democrática e 
o controle da legalidade. Revista da Procuradoria Geral do Estado de São Paulo, São Paulo, n. 47/48, p. 115-123, jan./dez. 1997. Disponível em: <http://www.pge.sp.gov.br/centrodeestudos/revistaspge/revista3/rev7.htm>. Acesso em: 29 jun. 2006.

MENDES, Gilmar Ferreira. Jurisdição constitucional: o controle abstrato de normas no Brasil e na Alemanha. 4. ed. São Paulo: Saraiva, 2004.

MENDES, Gilmar Ferreira. Direitos fundamentais e controle de constitucionalidade: estudos de direito constitucional. 2. ed. São Paulo: Celso Bastos, 1999.

MEIRELLES, Hely Lopes. Direito administrativo brasileiro. 26. ed. São Paulo: Malheiros, 2001.

MOOG, Marcos Costa Vianna. O novo perfil da advocacia pública: juridicidade, realidade e efetividade. In: CONGRESSO NACIONAL DE PROCURADORES DE ESTADO, 31., 2005, Florianópolis. As perspectivas da advocacia pública e a nova ordem econômica. Florianópolis: $\mathrm{OAB} / \mathrm{SC}, 2006$. p.503-525.

MORAIS, Alexandre de. Direito constitucional. 8. ed. São Paulo: Atlas, 2000.

MOREIRA, João Batista Gomes. Direito administrativo: da rigidez autoritária à flexibilidade democrática. Belo Horizonte: Fórum, 2005.

MOREIRA NETO, Diogo de Figueiredo. Advocacia pública e o princípio da eficiência. Interesse Público, Porto Alegre, n. 4, out../dez. 1999.

NUNES, Rizzatto. Manual da monografia jurídica. 4. ed. São Paulo: Saraiva, 2002.

OLIVEIRA, Antônio Flávio de. Precatórios: aspectos administrativos, constitucionais, financeiros e processuais. Belo Horizonte: Fórum, 2005.

OMMATI, Fides Angélica. Advocacia pública - algumas reflexões. Jus Navigandi, Teresina, ano 5, n. 51, out. 2001. Disponível em: < http://www1.jus.com.br/doutrina/texto.asp?id= 2111>. Acesso em: 03 maio 2004.

PRIETO SANCHÍS, Luis. Observaciones sobre las antinomias y el criterio de ponderación. Diritto Ẽ questioni pubbliche, Palermo, n. 2, p. 97-114, ago. 2002. Disponível em: < http:// www.dirittoequestionipubbliche.org/D_Q-2/contributi.htm>. Acesso em: 20 jun. 2006.

SILVA. José Afonso da. Curso de direito constitucional positivo. 16. ed. São Paulo: Malheiros, 1999.

SOARES, Mário Lúcio Quintão. Teoria do Estado. Belo Horizonte: Del Rey, 2001.

SOUTO, Marcos Juruena Villela. O papel da advocacia pública no controle da legalidade da administração. Interesse Público, Porto Alegre, ano 6, n. 28, p. 48-63, nov./dez. 2004.

STRECK, Lenio Luiz; MORAIS, José Luis Bolzan de. Ciência política e teoria geral do estado. 2. ed. Porto Alegre: Livr. do Advogado, 2001.

SUNDFELD, Carlos Ari. Fundamentos de direito público. 4. ed. São Paulo: Malheiros, 2001.

SUNDFELD, Carlos Ari. Princípio da impessoalidade e abuso e abuso do poder de legislar. Revista Trimestral de Direito Público, São Paulo, v. 5, n. 161, 1994.

TOURINHO FILHO, Fernando da Costa. Processo penal, 4 v. 19. ed. São Paulo: Saraiva, 1997.

VELOSO, Zeno. Controle jurisdicional de constitucionalidade. 3. ed. Belo Horizonte: Del Rey, 2003.

ZANDONAI, Marisa. Art. 132 da Constituição Federal - interpretação e alcance no âmbito da administracão pública - análise jurisprudencial. In: GONGRESSO NAGIONAL DE A \& C R. de Dir. Administrativo e Constitucional, Belo Horizonte, ano 7, n. 28, p. 45-75, abr./jun. 2007 
PROCURADORES DE ESTADO, 31, 2005, Florianópolis. VENTURA, Zênio; FAGUNDES, Paulo Roney Ávila (Org.). As perspectivas da advocacia pública e a nova ordem econômica. Florianópolis: OAB/SC, 2006. p. 372-402.

Informação bibliográfica deste texto, conforme a NBR 6023:2002 da Associação Brasileira de Normas Técnicas (ABNT):

GRANDE JÚNIOR, Cláudio. Superação das antinomias entre a legislação e a Constituição no exercício da advocacia pública. A\&C Revista de Direito Administrativo e Constitucional, Belo Horizonte, ano 7, n. 28, p. 45-75, abr./jun. 2007. 